\title{
Improving Lecturer Performance: The Role Of Locus Of Control, Motivation And Competence
}

\author{
Mochammad Munir Rachman $^{1 *}$, Sugijanto ${ }^{2}$, and Ch. Menuk Handayani ${ }^{3}$ \\ ${ }^{1,2}$ Department of Management, Faculty of Economics and Business, PGRI Adi Buana University, \\ Surabaya, Indonesia \\ ${ }^{3}$ Department of Accounting, Faculty of Economics and Business, PGRIi Adi Buana University, \\ Surabaya, Indonesia \\ Email address: \\ hnn_munir@yahoo.com; sugijanto@unipasby.ac.id, menuk@unipasby.ac.id \\ *Corresponding author
}

\begin{abstract}
This study aims to discuss the performance of lecturers, because locus of control plays a role in in improving their performance, and is supported by motivation and competence. With the explanatory method, 200 samples were obtained from distributing questionnaires, and using SEM analysis. As a result, locus of control has an effect on motivation and competence, and has a negative effect on lecturer performance. It is characterized by the absence of changes in behavior and attitudes, they still expect fate, luck, and other support for closeness to the ruler, external support is stronger than internal locus of control. They prefer to wait for the actions of others, as long as they can meet their performance needs. Motivation and competence have a fairly good influence in supporting their performance improvement. This situation occurs because their belief, effort, ability, and independence in producing a successful performance are still weak compared to fate.
\end{abstract}

Keyword: locus of control, motivation, competence, performance.

\begin{abstract}
Abstrak: Penelitian ini bertujuan untuk membahas kinerja dosen, karena locus of control berperan dalam kinerjanya, serta didukung oleh motivasi dan kompetensi. Dengan metode explanatory diperoleh 200 sampel dari penyebaran kuesioner, dan menggunakan analisis SEM. Akibatnya, locus of control berpengaruh terhadap motivasi dan kompetensi, serta berpengaruh negatif terhadap kinerja dosen. Hal ini ditandai dengan tidak adanya perubahan perilaku dan sikap, mereka masih mengharapkan nasib, keberuntungan, dan dukungan lain untuk kedekatan dengan penguasa, dukungan eksternal lebih kuat daripada locus of control internal. Mereka lebih memilih menunggu dari tindakan orang lain, selama mereka bisa memenuhi kebutuhan kinerja mereka. Motivasi dan kompetensi memiliki pengaruh yang cukup baik dalam mendukung peningkatan kinerja mereka. Situasi ini terjadi karena keyakinan, usaha, kemampuan, dan kemandirian mereka dalam menghasilkan kinerja yang sukses masih lemah dibanding nasib.
\end{abstract}

Kata kunci: locus of control, motivasi, kompetensi, kinerja. 


\section{INTRODUCTION}

Changes in the world of education during the pandemic, need to equip individual lecturers to innovate and build creativity in the learning process. This is a strategic and competitive challenge to produce high performance. Performance as a result of individual employee achievements in carrying out the tasks assigned by the organization (Rachman, 2017).

According to (Robbins and Judge, 2019), employee performance is an individual who carries out duties and responsibilities that contribute to work results. The success of achieving individual performance is not only the result of achievement, but the locus of control that is owned so that it is able to support the work activities carried out. Like a phenomenon in universities, lecturers still have not shown the results of their performance. Lecturers have not shown independence, effort and confidence or belief in the work they do. They tend to wait for fate, luck, or a stronger external force as an external locus of control. This can be seen in their behavior, they tend to choose passively to develop lesson plans, have not been able to take full advantage of the learning process, such as in pandemic conditions, lack of willingness to conduct research and active participation in outside scientific activities, lack of publication of scientific papers both internationally and nationally reputation, or in journals indexed by international databases, and other activities related to Tri Dharma. This is proven to be still low in producing their performance achievements. They prefer fate and luck, the consequences of which can have an impact on the university. This can also be related to other factors that cause dissatisfaction, so that it also affects their motivation and work competence factors to decrease, creative and innovative are also less responsive. Some researchers claim locus of control is able to produce their performance. Although there are other researchers who claim locus of control has a positive influence.

According to (Heywood et al., 2016) that locus of control plays a greater role in selecting assessments when workers have a low risk tolerance. As risk acceptance grows, workers are more likely to be in jobs with performance appraisals but the influence of the locus of control on selection decreases. Another study, (Rachman, 2012) and (Mali, 2013), that there is a positive relationship between internal locus of control and employee performance.

The success of the performance achieved shows the independence and confidence of employees who are able to fulfill their desires, while job satisfaction as a support is influenced by the interaction between the level of involvement and the type of locus of control owned by the employee. So, when a positive relationship between internal and external locus of control with the achievement of individual performance is a belief, what happens to him, his failure or success, because the influence is on themselves.

According to (Rachman, 2012), lecturers have the ability, skills, and a strong understanding of what it takes to succeed and belief in one's ability to succeed. Logically, the events experienced can change fate, because his confidence is based on experience, and is able to form high performance, so that his success is identical to understanding in achieving achievements in the field of Tri Dharma. However, other researchers discuss the development of an internal locus of control that is used to improve individual performance 
rather than an external locus of control, in addition to that, it is also carried out by utilizing the relationship of motivation as an individual's performance achievement.

Acording to (Robbins and Judge, 2019), stated motivation as a process that explains the intensity for a person, direction and persistence of effort to achieve an organizational goal. The locus of control relationship on performance through intrinsic motivation has the first indication that employees have (Sundjoto, 2017), and motivation not only has the urge to do something (drive) at work but more than that, motivation is expected to meet the needs of an individual to life and in accordance with the achievement of their individual performance results.

Reviewing the success of an objective lecturer performance assessment is always based on motivation, feedback and competence based on professional competency standards. As with professional competence, lecturers have and develop abilities, knowledge, skills, and behaviors or attitudes to act more objectively in achieving effective performance (Rachman, 2012). In accordance with the workload of lecturers (BKD) in Law no. 14 of 2005 has provided a clear answer. A lecturer is called a professional, while a lecturer's competence is stated as a set of knowledge, skills and behaviors that must be possessed, internalized, mastered and realized by the lecturer in carrying out his professional duties. Competence is a basic characteristic and individual ability that is related to a person's performance standards and criteria effectively, and excels at always working with observable and measurable behavior, because this is part of his job. Researchers (Alainati et al., 2011), that competence is more directed at competencies that are beneficial to individual competencies and are applied properly because they have a positive effect on employees for the performance that has been achieved.

Several other researchers discussed the relationship of locus of control to employee performance such as (Dali and Mas'ud, 2014); (Loice, 2014); (Susanne, 2017); (Kusuma et al., 2018); (Djou and Lukiastuti, 2020); (Mulyani et al., 2019); (Kriswantini and Sososutikno, 2020), that understanding the locus of control is very important for the success of achieving good performance. They believe that the critical success factor is the ability, independence and self-confidence to solve work problems (internal locus of control), although some people believe that achieving success is much more determined by luck, proximity to policy makers (external locus of control).

The same researchers as (Muindi, 2015), (Fagbola and Popoola, 2015), (Ahluwalia and Preet, 2017), (Lestariningsih, 2017), that locus of control can improve employee performance in meeting organizational goals. Therefore, competence focuses more on multicultural skills, understanding, introducing something and changing the organization, self-control or locus of control and emotional intelligence/intelligence and people skills.

Then (Tiyanto, 2010); (Djou and Lukiastuti, 2019), revealed that employees understand the benefits of competence to improve work performance and the success of organizational goals. The positive influence of employees is able to change behavior and support the success of organizational goals. If a person's competence is assessed, it can be predicted based on the achievement of the person's performance results. Therefore, in identifying the problems that occur, it is necessary to understand the relationship between variables on the role of locus of control on lecturer performance through motivation and competence as supporters. 


\section{THEORITICAL REVIEW}

Locus of Control. Locus of control is one of the personality variables, and describes a person's beliefs about the factors that influence his behavior (Jung, 1978). As an internal locus of control, individuals have their own perceptions, behaviors, and attitudes that will result in positive success, and situations where support occurs according to the individual's attitude as the individual's internal locus of control, while he assesses the situation, after that support occurs from the individual's attitude as an individual's external locus of control. Therefore, individual beliefs depend on his own destiny, relative, and tend to be more successful in careers. He called it, the core of the locus of control theory explains the control center, and the center of direction of each behavior. The locus of control measurement scale is continuum, meaning that sometimes a person has an internal locus of control tendency, and sometimes an external locus of control tendency. If individuals person with an internal locus of control tend to believe that their skills, abilities, and efforts will determine what they achieve in their lives, whereas individuals with an external locus of control will have their lives determined by external forces. I believe, much of their success is supported by fate or destiny, luck, and other rulers. They believe that their destiny is determined by chance or forces over which they have no control.

In reaction to the experience of failure, the internal shift towards the external, but those from the external do not shift in the internal direction after the successful experience. Other researchers from (Dali and Mas'ud, 2014), (Kusuma et al., 2018), stated that internal locus of control tends to be a priority because it has a positive and significant effect on people's work outcomes, but is not so focused on locus of control. external controls. Meanwhile, (Angelova, 2016), that locus of control has a significant influence on performance. Locus of control is related to individual acceptance and responsibility as a result of his own behavior (Nerguz et al., 2010). In contrast to (Sundari, 2014), that one of the factors that influence the development of locus of control is the physical and social environment.

Motivation. The most tedious task of leadership for its members is to motivate. Sometimes the enthusiasm is high, sometimes it becomes low, after getting encouragement from the leader in his work activities. (Rachman, 2020), motivation is an effort to encourage an individual or team that has direction and goals to be achieved to get satisfaction. The achievement results depend on the situation and conditions faced by an individual or team in carrying out their work activities. (Luthans, 2015) states that motive is an internal drive that creates energy and activities that move people to behave to achieve goals. Likewise, (Robbins and Judge, 2019) motivation as the processes that account for an individual's intensity, direction, and persistence of effort toward attaining a goal. While general motivation is concerned with effort toward any goal, we'll narrow the focus to organizational goals, while (Gibson et al., 2013), that motivation is a concept that we use to describe the drives that arise in or within a person. Individuals who drive and direct behavior.

So far, the theory of motivation related to the development of individual behavior and attitudes has been widely discussed in Maslow's hierarchy of needs which was developed by adding two indicators of needs. As (Rachman et al., 2020), that motivation is 
aimed at meeting needs and satisfaction both psychologically and business management, known as the hierarchical model which has been expanded to become eight stages as measurement indicators, including: (1) biological and physiological needs, (2) security needs, (3) belongingness and love needs, (4) self-esteem needs, (5) cognitive needs, (6) needs aesthetic, (7) self-actualization needs, and (8) the need for transcendence.

Furthermore, Maslow's motivational theory model is described in the form of a hierarchy of 8 (eight) stages of people's needs as shown in Figure 1.

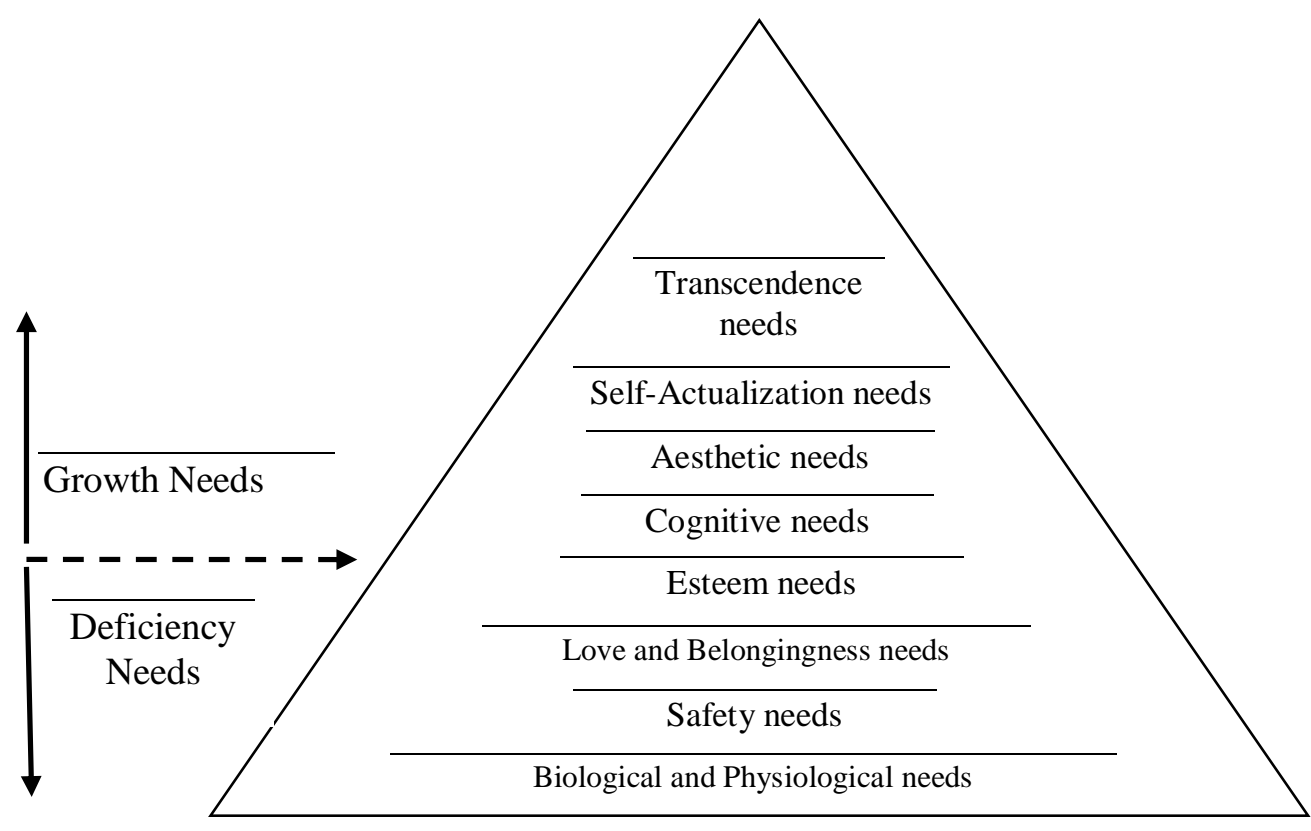

Figure 1. Maslow's Hierarchy of Needs

Source: Maslow's Psychological Theory, 1987.

Competence. Competence is actually not new in organizations. Competency needs and predicting future organizations built around people. They add that competence will be lacking because there is an emphasis on work as a workplace in the organization; on the other hand, increased attention will focus on employee competencies. If so, competence or what they bring to the job becomes important. It is a competency approach to selection, and assessment based on classifying, identifying, and measuring individual differences for certain construction-related jobs that are relevant to successful job performance (Bartram, 2004). These findings have sparked interest in the study of competency variables that predict individual performance. Many people interpret competence as a person's ability to produce work. The effectiveness of a work is strongly influenced by the skills, knowledge, behavior (attitudes), and abilities that are in accordance with the work.

According to (Mathis and Jackson, 2010) that competence includes knowledge, skills and skills and may be a basic characteristic that will be associated with individual performance. what is meant by motives, self-concept, traits, knowledge and abilities/skills. 
Individual competencies possessed in the form of abilities and knowledge are often developed through education and training. Competence during work is the ability of employees to realize (or exceed) the pressure of the expected quality level of the workforce in various situations both inside and outside the organization. These competencies. Then in the RI Law No. 14 of 2005 that lecturers have duties and responsibilities as professional educators, have a set of knowledge, skills, and behaviors that are owned, lived, mastered and actualized.

His professional duties have benchmarks as the workload carried out including; (1) ownership of academic qualifications and performance of the tridharma, (2) ownership of competencies that are measured perceptually by students, themselves, colleagues and superiors, (3) self-assessment of the contribution made in the implementation and development of the tridharma, and (4) honesty in acknowledging their strengths and weaknesses and efforts to improve themselves. In essence, the full picture of lecturer competence includes (a) in-depth introduction to students; (b) mastery of fields of study related to scientific disciplines and teaching materials in accordance with the higher education curriculum; (c) implementation of educational learning, including planning and implementation of learning, evaluation of learning processes and outcomes, as well as follow-up improvements and enrichment; and (d) continuous evaluation of the learning process and outcomes.

Performance. Job performance as a result of the behavior of people in trying to meet the goals achieved in accordance with the burden provided by the organization. Meanwhile, (Bernardin and Rusel, 2013), reveal that performance is something that is produced by having a record of the results obtained from certain job functions or activities over a certain period of time. According to (Mangkunegara, 2017), employee performance is the result of individuals carrying out their duties in accordance with the responsibilities given to them both in terms of quality and quantity. Then performance according to (Ramsden, 2003), is that someone tends to be in a higher education institution, but an assessment or assessment of a teacher is one way to find out the impact of a teacher's education on students. This is shown by assessing the quality of faculty performance in education or learning, research and community service, as well as other supporting activities related to the Tri Dharma. As stated in the Regulation of the Minister of National Education No. 18 of 2007 to serve as the basis for implementing the objectives of the lecturer performance assessment, namely: (1) academic qualifications, (2) improving the quality of teaching, research/scientific works, and community service, (3) assessment by oneself, colleagues, direct superiors, and students, (4) awards relevant to Tridharma, (5) participation or participation in scientific forums and their roles, (6) developing lecturer competencies, (7) professional development.

Conceptual Framework Model. This study examines the locus of control of lecturers in higher education on the performance of lecturers with motivation and competence as supporters in producing maximum work results in accordance with the university's objectives described below; 


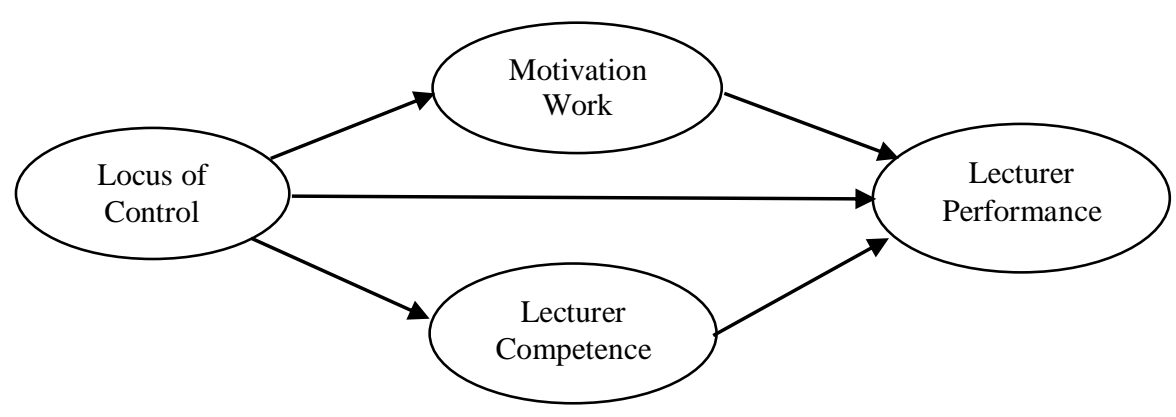

Figure 2. Conceptual Framework

Based on the problems that have been formulated and the conceptual framework model, the hypotheses of this research can be proposed as follows: (1) Locus of control effect of lecturer performance. (2)Locus of control improve effect of lecturer performance if it is related to motivation. (3) Locus of control improve effect of lecturer performance if it is related to competence.

\section{METHODS}

Research Design. This research design is prepared according to the procedure, and it is important to obtain the information needed in compiling, and solving research problems. This research design model uses the explanatory method, meaning that it aims to analyze the relationship between one variable and other variables that influence it (Rachman, 2018). Furthermore, this study has 25 indicators with 4 latent variable constructs. Therefore, the research sample taken using the proportional stratified random sampling technique was obtained as many as 200 respondents, where the sampling technique for permanent lecturers from 22 private universities in Surabaya at the economics and business faculties was 782 lecturers, but not all of them could be samples. Considering that the use of SEM analysis is carried out by taking into account the number of observation indicators, so it is calculated by multiplying the number of observation indicators between numbers 5 to 10 (Rachman, 2018).

Data Analysis Technique. This analysis technique is based on the objectives studied, the data collected can be processed according to needs, and tested through instrument testing by applying Structural Equation Modeling (SEM) as the modeling used for measurement and confirmatory factor analysis as a test of the significance of the variable indicator (indicator model). Reflective) which is studied because it is formed, and affects the latent construct (Rachman, 2018). 


\section{RESULTS}

Instrument Analysis. The statistical test of this research instrument used 200 research data which was carried out with validity and reliability tests. Validity test is a measure that shows the validity or instrument validity in the form of results of the recapitulation of the analyzed data shown below.

Locus of control validity test analysis. Statistical test results for the locus of control instrument as shown in table 1.

Table 1. Locus of Control Validity Test Analysis

\begin{tabular}{lcc}
\hline \multicolumn{1}{c}{ Instruments } & $\begin{array}{c}\text { Corrected Item- } \\
\text { Total Correlation }\end{array}$ & Description \\
\hline Skills in carrying out work & .667 & Valid \\
Ability to complete work without difficulty & .825 & Valid \\
Always try and be independent in completing his work & .718 & Valid \\
Its success is always supported by fate or destiny & .851 & Valid \\
Luck is always obtained in completing the work & .736 & Valid \\
The power of the ruling party always supports his work & .752 & Valid \\
\hline
\end{tabular}

Source: from the analysis of primary data processed

Based on table 1 states that the overall locus of control indicator items analyzed are able to show validity results, because all the coefficients of the total correlation items have a weighted validity value greater than the critical value of 0.30 . It means that all locus of control indicator items as research instruments can be accepted statistically.

Work motivation validity test analysis. Statistical test results for the work motivation instrument as shown in table 2 .

Table 2. Work Motivation Validity Test Analysis

\begin{tabular}{lcc}
\hline \multicolumn{1}{c}{ Instruments } & $\begin{array}{c}\text { Corrected Item-Total } \\
\text { Correlation }\end{array}$ & Description \\
\hline To meet the necessities of life & .631 & Valid \\
To get a sense of security and comfort at work & .409 & Valid \\
To establish a social life and a sense of comfort in the & .676 & Valid \\
surrounding environment & & Valid \\
Confidence and independence to maintain self-esteem at work & .557 & Valid \\
The need to explore or openness to work experience & .550 & Valid \\
The need for a beautiful image or something new and fun to & .537 & Valid \\
get to Self-Actualization & & Non-valid \\
$\begin{array}{l}\text { Desired needs as a form of achievement for the abilities he has } \\
\text { The need for transcendence for others to be more motivated by } \\
\text { values beyond oneself }\end{array}$ & .395 & .257 \\
\end{tabular}

Source: from the analysis of primary data processed 
Based on table 2 states that the overall work motivation indicator items analyzed are able to show validity results, because all the coefficients of the total correlation items have a weighted validity value greater than the critical value of 0.30 , except for the transcendence indicator item which has a coefficient weight of 0.257 smaller than 0.30 so that it is declared invalid. It means that all work motivation indicator items as research instruments can be accepted statistically.

Lecturer competence validity test analysis. Statistical test results for the lecturer competence instrument as shown in table 3.

Table 3. Lecturer Competence Validity Test Analysis

\begin{tabular}{lcc}
\hline \multicolumn{1}{c}{ Instruments } & $\begin{array}{c}\text { Corrected Item- } \\
\text { Total Correlation }\end{array}$ & \begin{tabular}{c} 
Description \\
\hline $\begin{array}{l}\text { Get to know students in depth to be able to receive knowledge } \\
\text { transfer }\end{array}$
\end{tabular} \\
$\begin{array}{l}\text { Develop mastery of scientific disciplines in accordance with their } \\
\text { abilities }\end{array}$ & .581 & Valid \\
$\begin{array}{l}\text { Contribute to the implementation of learning and development of } \\
\text { the tridharma }\end{array}$ & .742 & Valid \\
$\begin{array}{l}\text { Develop personality and professionalism on an ongoing basis and } \\
\text { efforts to improve yourself }\end{array}$ & .636 & Valid \\
\hline $\begin{array}{l}\text { Source. from the analysis of primary data processed } \\
\end{array}$
\end{tabular}

Source: from the analysis of primary data processed

Based on table 3 states that the overall lecturer competence indicator items analyzed are able to show validity results, because all the coefficients of the total correlation items have a weighted validity value greater than the critical value of 0.30 except for the scientific disciplines indicator item which has a coefficient weight of 0.172 smaller than 0.30 so that it is declared invalid. It means that all lecturer competence indicator items as research instruments can be accepted statistically.

Lecturer performance validity test analysis. Statistical test results for the lecturer performance instrument as shown in table 4.

Table 4. Lecturer Performance Validity Test Analysis

\begin{tabular}{|c|c|c|}
\hline Instruments & $\begin{array}{l}\text { Corrected Item- } \\
\text { Total Correlation }\end{array}$ & Description \\
\hline Able to master academic qualifications & .594 & Valid \\
\hline $\begin{array}{l}\text { Able to improve the quality of teaching, research/scientific work, } \\
\text { and community service }\end{array}$ & .509 & Valid \\
\hline $\begin{array}{l}\text { Openness to self-assessment, peers, direct supervisors, and } \\
\text { students }\end{array}$ & .604 & Valid \\
\hline Ability to obtain awards relevant to the Tridharma & 620 & Valid \\
\hline Participation or participation in scientific forums and their role & .212 & Non-valid \\
\hline Able to develop his competence as a lecturer profession & .496 & Valid \\
\hline Carry out professional development & .132 & Non-valid \\
\hline
\end{tabular}


Based on table 4 states that the overall lecturer performance indicator items analyzed are able to show validity results, because all the coefficients of the total correlation items have a weighted validity value greater than the critical value of 0.30 . except for the participation in scientific forums indicator item which has a coefficient weight of 0.212 smaller than 0.30 so that it is declared invalid, and professional development indicator item which has a coefficient weight of 0.132 smaller than 0.30 so that it is declared invalid. It means that all lecturer performance indicator items as research instruments can be accepted statistically.

Then checked with the reliability test which states the extent to which a measuring instrument can be trusted and reliable on the results of this study, then measurements are carried out as analyzed in the table 5.

Table 5. Reliability Test Analysis

\begin{tabular}{l|c|l}
\hline \multicolumn{1}{c|}{ Variable } & Cronbach's Alpha & Description \\
\hline Locus of control & .913 & Reliable \\
\hline Word Motivation & .794 & Reliable \\
\hline Lecturer Competence & .726 & Reliable \\
\hline Lecturer Performance & .724 & Reliable \\
\hline Critical value $\alpha=0,05$ & & Bigger than 0,60 \\
\hline Source: from the analys of primary
\end{tabular}

Source: from the analysis of primary data processed

From table 5 above, it shows that the overall indicator variables measured based on observations from the results of the questionnaire distribution show the weight of the Cronbach's Alpha coefficient, each indicator has a coefficient weight greater than 0.60 and is declared reliable. Therefore, the questionnaire distributed to the respondents could be accepted and continued for research.

Structural Equation Modeling Analysis. Prior to the statistical test, the observed indicators were tested using the measurement model process or confirmatory factor analysis (CFA) test. The results of the CFA analysis of each construct can be shown as follows:

Locus of Control Confirmatory Factor Analysis. The locus of control in this confirmatory model consists of 6 indicator dimensions formed by the construct so that it gets the meaning of the extracted indicators on the standardized loading factor value and the results are significant. As shown in Table 6.

Table 6. Locus of Control Standardized Loading Factor

\begin{tabular}{ll|rrl}
\hline & & Estimate & P & Description \\
\hline x1 <--- & Locus_of_Control &, 652 & 0,000 & Significant \\
x2 <--- & Locus_of_Control &, 859 & 0,000 & Significant \\
x3 <--- & Locus_of_Control &, 732 & 0,000 & Significant \\
x4 <--- & Locus_of_Control &, 911 & 0,000 & Significant \\
x5 <--- & Locus_of_Control &, 781 & 0,000 & Significant \\
x6 <--- & Locus_of_Control &, 812 & 0,000 & Significant \\
\hline
\end{tabular}


Based on Table 6. shows that the standardized loading factor analyzed has an overall loading factor value that meets the requirements of 0.50 , so it can be concluded that the exogenous construct forming indicators used are valid. The results of the confirmatory factor analysis model described by Locus of Control on the four indicators were able to form the structural equation modeling in this study well, thus accepting the theoretical concepts used in the study.

Work Motivation Confirmatory Factors Analysis. Work motivation in this confirmatory model consists of 8 indicator dimensions formed by the construct so that it gets the meaning of the extracted indicators on the standardized loading factor value and the results are significant. As shown in Table 7.

Table 7. Work Motivation Standardized Loading Factor

\begin{tabular}{rl|rrl}
\hline & & Estimate & P & Description \\
\hline x7 <--- & Work_Motivation &, 656 & 0,000 & Significant \\
x8 <--- & Work_Motivation &, 811 & 0,000 & Significant \\
x10 <--- & Work_Motivation &, 622 & 0,000 & Significant \\
x11 <--- & Work_Motivation &, 712 & 0,000 & Significant \\
x13 <--- & Work_Motivation &, 324 & 0,000 & Significant \\
x14 <--- & Work_Motivation &, 198 & 0,019 & Significant \\
x12 <--- & Work_Motivation &, 689 & 0,000 & Significant \\
x8 <--- & Work_Motivation &, 334 & 0,000 & Significant \\
\hline
\end{tabular}

Source: from the analysis of primary data processed

Based on Table 7 shows that the standardized loading factor analyzed has an overall loading factor value that meets the requirements of 0.50 , which shows significant results so that it can be concluded that the exogenous construct-forming indicators used are quite valid. The results of the confirmatory factor analysis model described by work motivation on the eight indicators were able to form the structural equation modeling in this study quite well, thus accepting the theoretical concepts used in the study.

Lecturer Competence Confirmatory Factors Analysis. Lecturer competencies in this confirmatory model consist of 5 indicator dimensions formed by the construct so that it gets the meaning of the extracted indicators on the standardized loading factor value and significant results. As shown in Table 8.

Table 8. Lecturer Competence Standardized Loading Factor

\begin{tabular}{cl|rrc}
\hline & & Estimate & P & Description \\
\hline x15 <--- & Lecturer_Competence &, 731 & 0,000 & Significant \\
x18 <--- & Lecturer_Competence &, 768 & 0,000 & Significant \\
x17 <--- & Lecturer_Competence &, 924 & 0,000 & Significant \\
x16 <--- & Lecturer_Competence &, 154 & 0,059 & Non-significant \\
\hline
\end{tabular}

Source: from the analysis of primary data processed

Based on Table 8 , it shows that the standardized loading factor analyzed has an overall loading factor value that has met the requirements of 0.50 except for the relationship between lecturer competence and the x13 indicator, so it can be concluded 
that the exogenous construct-forming indicators used are valid. The results of the confirmatory factor analysis model explained by the competence of the lecturers on the four indicators were able to form the structural equation modeling in this study well, thus accepting the theoretical concepts used in the study.

Lecturer Performance Confirmatory Factor Analysis. The lecturer's performance in this confirmatory model consists of 6 indicator dimensions formed by the construct so that it gets the meaning of the extracted indicators on the standardized loading factor value and the results are significant. As shown in Table 9.

Table 9. Lecturer Performance Standardized Loading Factor

\begin{tabular}{ll|rrc}
\hline & & Estimate & P & Description \\
\hline x19 <--- & Lecturer_Performance &, 743 & 0,000 & Significant \\
x20 --- & Lecturer_Performance &, 588 & 0,000 & Significant \\
x21 <--- & Lecturer_Performance &, 729 & 0,000 & Significant \\
x22 <--- & Lecturer_Performance &, 746 & 0,000 & Significant \\
x23 <--- & Lecturer_Performance &, 322 & 0,000 & Significant \\
x24 <--- & Lecturer_Performance &, 638 & 0,000 & Significant \\
x25 <--- & Lecturer_Performance &, 136 & 0,107 & Non-significant \\
\hline
\end{tabular}

Source: from the analysis of primary data processed

Based on Table 9, it shows that the standardized loading factor analyzed has an overall loading factor value that has met the requirements of 0.50 , except for the relationship between lecturer performance and the x 25 construct, so it can be concluded that the indicators forming the exogenous construct used are valid. The results of the confirmatory factor analysis model described by the lecturer's performance on the seven indicators were able to form the structural equation modeling in this study well, thus accepting the theoretical concepts used in the study.

The results of the CFA analysis of the four constructs; locus of control, motivation, competence and performance of each indicator has significant results, because $\mathrm{p}$ smaller than 0.050; except from the 16th indicator, other supporting activities related to Tri Dharma have $\mathrm{p}$ together than 0.059 bigger than 0.050 and the results are not significant on competence, then the 25th indicator is professional development which has p together than 0.107 bigger than 0.050 the results are not significant on lecturer performance. However, the researchers continued to analyze the model built from each latent construct with Structural Equation Modeling (SEM) analysis.

Data Normality Evaluation. Analysis of the value of cr and kurtosis in the range of -2.58 among 2.58; indicated by the value of the critical ratio skewness on the value of all indicators showing that the data is normally distributed because the value is below 2.58 , while the multivariate normality test results in a cr of 4.233 above the value of 2.58 . It means that the results of the normality analysis of the data state that the multivariate data is normally distributed, but in this study the data can still be analyzed using Structural Equation Modeling (SEM). 
Evaluation of Multicollinearity and Singularity. Analysis of multicollinearity and singularity on the determinant of the sample covariance matrix (Determinant of sample covariance matrix) is indicated by a coefficient value of 4.732 bigger than 0.000 , and there are no symptoms of multicollinearity and singularity, so the resulting data is still feasible and can be continued as research data.

Evaluation of Goodness of Fit Index on SEM. The analysis of structural relationships between variables or structural equation modeling that is tested for suitability or Goodness of Fit indices to respecify the model with the same residual constraint for 4 first-order constructs with variance, can make a covariance relationship between errors as modified as shown in the following Figure 3.

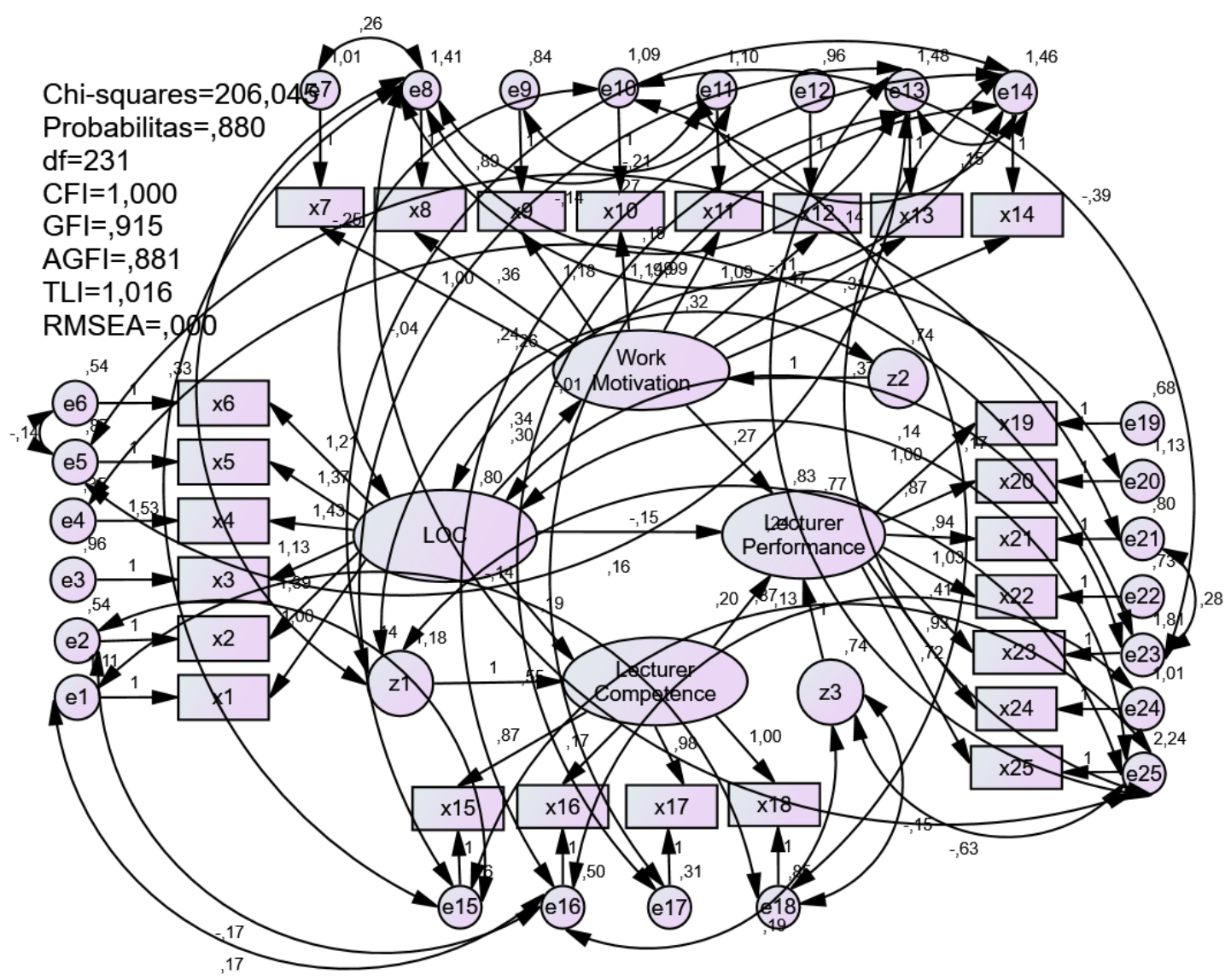

Figure 3. Model Relationship Between Constructs With SEM Analysis

Based on Figure 3, shows the statistical suitability of the SEM output model obtained through chi-squares of 206.045 with prob. 0.880 and also indicated by the Goodness of Fit value as shown in Table 10. 
Table 10. Goodness of Fit Analysis

\begin{tabular}{l|ccc}
\hline Goodness of Fit Indices & Analysis Result df. 231 & Cut-off Value & Evaluation Model \\
\hline Chi-Squares & 206,045 & Expected small & Not good \\
CMIN/DF & 0,892 & $\leq 2,00$ & Good \\
Significance Probability & 0,880 & $\geq 0,05$ & Good \\
RMSEA & 0,000 & $\leq 0,08$ & Good \\
GFI & 0,915 & $\geq 0,90$ & Good \\
AGFI & 0,881 & $\leq 0,90$ & Marginal \\
TLI & 1,016 & $\geq 0,95$ & Good \\
CFI & 1,000 & $\geq 0,95$ & Good \\
NFI & 0,910 & $\geq 0,90$ & Good \\
\hline
\end{tabular}

Source: from the analysis of primary data processed

From Table 10, the analysis of the goodness of fit indices of the structural model shows that the resulting data is fit, and has met all the required criteria, except for the chisquare result which is stated to be poor. However, the analysis of the model for respecification which is prepared with constraints is still accepted by the analysis of the model. Thus the structural model analyzed in this study has been accepted, because there is no difference between the sample covariance matrix and the estimated population covariance matrix, so the model used in this study is acceptable. The next step is to analyze the estimate parameter.

The discussion of the results studied is based on the formulation of the problem proposed, if the results of the analysis are acceptable, it means that the probability is $p$ 0.05. Therefore, in clarifying the SEM analysis model used, it can be shown the Standardized Regression Weights analysis as shown in Table 11.

Table 11 Standardized Regression Weight Analysis

\begin{tabular}{ll|rrrrl}
\hline & & Estimate & S.E. & C.R. & P & Description \\
\hline Work_Motivation & <--- LOC & 0,299 & 0,095 & 3,171 & 0,002 & Significant \\
Lecturer_Competence & $<---$ LOC & 0,152 & 0,083 & 2,265 & 0,024 & Significant \\
Lecturer_Performance & $<---$ Work_Motivation & 0,256 & 0,098 & 2,695 & 0,007 & Significant \\
Lecturer_Performance & $<---$ Lecturer_Competence & 0,237 & 0,081 & 2,498 & 0,012 & Significant \\
Lecturer_Performance & $<---$ LOC & $-0,141$ & 0,094 & $-1,580$ & 0,114 & Non significant \\
\hline
\end{tabular}

Source: from from the analysis of primary data processed

From Table 11, this finding shows that the value of the regression weight coefficient on the effect of locus of control on lecturer motivation has an estimate of 0.299 with a probability of 0.002 or $\mathrm{p}$ smaller than 0.05 and the results are positive and significant with the regression weight. The positive influence of locus of control on lecturer motivation shows that the lecturer's self-ability to carry out tasks and responsibilities for the work carried out has fulfilled organizational goals. Therefore, the locus of control that arises from the lecturer both internally and externally is able to increase the effectiveness of the 
self-control center in completing his work so that the desire to achieve goals is carried out by showing high motivation.

The effect of locus of control on the competence of lecturers as indicated by the standardized regression weight coefficient value in the estimate of 0.152 with a probability of 0.024 or $\mathrm{p}$ smaller than 0.05 and the results are positive and significant with the regression weight. The positive and significant effect of locus of control on competence shows that the ability of lecturers in the center of self-control on the work done is not supported by the expertise and knowledge possessed. The higher the lecturer's self-control center in improving the work done, the higher the competence of the lecturers in achieving the results of their work, so that the work activities they carry out are able to meet organizational goals, without support from outside parties.

The effect of work motivation on lecturer performance is indicated by the value of the standardized regression weight coefficient in the estimate of 0.256 with a probability of 0.007 or $\mathrm{p}$ smaller than 0.05 and the results are positive and significant with the regression weight. The positive effect of work motivation on lecturer performance shows good results. Lecturers have succeeded in carrying out workload activities and have met organizational goals. This shows that lecturers have high morale both internally and externally. Therefore, high motivation for them is able to produce high performance as well, because strong support from the leadership has changed their behavior to fulfill careers, positions and organizational goals in changing organizational environmental conditions for the better.

The influence of competence on lecturer performance as indicated by the standardized regression weight coefficient value in the estimate of 0.237 with a probability of 0.012 or $\mathrm{p}$ smaller than 0.05 and the results are positive and significant with the regression weight. The positive and significant influence on their performance shows that their activities on the workload have been carried out, in accordance with their professional duties. This is their duty and responsibility in achieving their performance. Therefore, organizational support for them can produce results in accordance with organizational goals.

The influence of locus of control to lecturer performance is shown by standardized regression weight analysis at an estimate of -0.141 with a probability of 0.114 or $p$ bigger than 0.05 . Means that locus of control has a negative effect on lecturer performance. The negative and insignificant effect of locus of control on the performance of the lecturers indicates a decrease in the work done by the lecturers. This shows that their self-control center in increasing their workload has not been able to utilize their capabilities internally and externally. Therefore, the leadership of the organization needs to be persuasive. and provide more support so that they realize the importance of improving the achievement of their performance results.

Furthermore, the results of the Standardized Regression Weights analysis which have an indirect relationship between exogenous and endogenous constructs are presented in the Table 12 below. 
Table 12. Standardized Indirect Effects Analysis

\begin{tabular}{l|rrrr}
\hline Indirect effects & LOC & Motivation_Job & Competence_Lecturer & Performance_Lecturer \\
\hline Motivation_Job &, 000 &, 000 &, 000 &, 000 \\
Competence_Lecturer &, 036 &, 000 &, 000 &, 000 \\
Performance_Lecturer &, 113 &, 039 &, 000 &, 000 \\
\hline
\end{tabular}

Source: from from the analysis of primary data processed

From Table 12, it is shown that the standardized estimate of 0.039 is the positive influence of locus of control on the performance of lecturers through their work motivation. Likewise, the locus of control relationship has an influence in improving the performance of lecturers through competence as indicated by the standardized estimate of 0.036. The positive influence of locus of control on lecturer performance both with motivation and competence is more important than the direct influence of locus of control on lecturer performance. Therefore, locus of control is stated to be able to change their behavior when they get support from motivation and competence and are considered important.

\section{DISCUSSION}

Statistical results as an analysis of the SEM model used with the conceptual framework model and the hypotheses proposed in the discussion are as follows.

The Influence of Locus of Control on Lecturer Performance.

Based on table 11 shows that locus of control has a negative effect on lecturer performance. The negative effect of locus of control on the performance of lecturers, indicates a decrease in the achievements of lecturers. This shows that the lecturer's locus of control in increasing work activities is not able to produce high success, as an internal locus of control. On the other hand, conditions like this tend to make more use of fate, luck, behavior and attitudes, and support from the authorities in obtaining successful performance results, as an external locus of control. So that individual lecturers in carrying out the duties of the Tri Dharma and other activities related to the Tri Dharma are unable to show their confidence to achieve success. The independence and self-confidence they have feel are not free or pressured by the tasks assigned by the organization. In such a situation, they prefer to wait, and support from others in achieving success. This happens because their belief, effort, ability, and independence in producing a successful performance are still weak, so they need strong support from external parties to motivate them.

The finding of the influence of locus of control which is supported by six construct indicators states that it is significant but has not been able to improve their performance in their results. Although related to the seven indicators of performance constructs, they have not been able to show satisfactory results, on the contrary, their achievements are decreasing. This is not only in the Carry out professional development indicator, but also the Participation or participation in scientific forums and their role indicators which are expected to be able to support have weakened. Because there are several performance indicators that produce low significance, only indicators of Openness to self-assessment, 
peers, direct supervisors, and students and Ability to obtain awards relevant to the Tridharma are stated moderate.

On the other hand, their work motivation was able to increase according to the university's expectations although there were several indicators that were found not to be able to support the achievement of high motivation in producing the university's expected performance in the management study program, except To meet the necessities of life and To establish a social life and a sense of comfort in the surrounding environment that supports the formation of lecturers' motivation in producing the results of their work. Likewise, the indicators of competence of lecturers who are faced with being able to produce high performance but have not been able to overall produce success in the achievement of their work. This all depends on the relationship between the constructs that are the foundation to be integrated in producing high performance. In fact, indicators on performance are still unable to change their attitudes and behavior because the support from performance indicators is still weak to change fate, luck and self-confidence to work with confident independence. The strong support from a more powerful outside which is still their dream even though the factor of waiting, fate or luck is still strong is their confidence in producing success, including indicators of developing scientific discipline in the achievement of their competencies, and participation in scientific meetings.

In theory, internal locus of control is able to improve the performance of individual people if self-confidence and self-confidence, effort, and ability to carry out high activities, and the hope of obtaining success can be achieved in line with organizational goals, on the contrary, individual self-confidence of people being a strength for the organization has not been able to be fulfilled because strong support from the factors of fate and luck. The findings of this study are not in line with researchers Susanne (2017); Kusuma et al., (2018); Djou and Lukiastuti (2019); Mulyani et al., (2019); Kriswantini and Sososutikno (2020), because hopes to improve lecturer performance with locus of control are not able to improve lecturer behavior and attitudes, they tend to wait for fate and luck as well as support from other more powerful parties. Success in supporting the organization has not been fully significant because there are factors of fate and luck. On the other hand, the failure to improve the performance of the lecturers has not fully reviewed the lecturers' performance. This is evidenced by the results achieved are still derived from fate and luck, and not stems from trying, independence or self-confidence in achieving the desired organization. This has an impact on the weak performance of lecturers to carry out high activities, they do not like challenges and are independent in updating high ideas for future development. They prefer the external locus of control factor.

Understanding the locus of control is very important for the success of achieving high performance, they believe that the critical success factor comes from the belief, effort, ability, and independence of individual lecturers in obtaining success in their work. On the other hand, the main priority for organizational leaders to succeed in the ability and independence of individual lecturers is to increase the internal locus of control in achieving success rather than external locus of control factors.

The Influence of Locus of Control on Lecturer Performance Through Motivation 
Likewise, from Table 12, it is shown that the positive influence of locus of control on the performance of lecturers through their work motivation. This indicates that lecturers have confidence or trust, and independence with internal self-control abilities can achieve fairly good success. The success achieved by lecturers in Tri Dharma activities, and other activities related to Tri Dharma can be carried out successfully, in contrast to weaker external self-control, because fate, behavior and attitudes, luck, and efforts to approach the authorities should be abandoned. So that success in improving the work performance of lecturers through stronger motivation to support independence, and reliable abilities can achieve great success. This is a sign that the lecturer has the ability to achieve the desired goals without obstacles to the workload for the achievement of high work performance.

The Influence of Locus of Control on Lecturer Performance Through Lecturer Competence

From Table 12, the achievement of their performance is not only motivational support from the leadership, but leaders also need to pay attention to the competence of lecturers who have been carried out as their workload. Competence is also important for them as a measurement of their performance results. This all depends on the locus of control relationship that the lecturers have which has been proven by the performance results they have achieved. Positive influence on locus of control on lecturer performance through competence indicates that lecturers have strong belief in the workload they are facing, even though some jobs in the Tri Dharma field are requirements, and challenges to produce high lecturer work performance. This is evidenced by strong independence, belief, ability, behavior and attitude, independence of lecturers who are supported by a strong internal locus of control capable of meeting the demands of a successful profession. In addition, the performance of lecturers with internal self-control is more trusted, and is believed to be able to achieve high success, while the support of external self-control only hopes for luck and fate which are considered weak in influencing the success of lecturers to improve their performance. So that the success of lecturers in achieving success in improving their performance has not been fulfilled, because the lecturer's internal locus of control is still weak in achieving high performance success compared to the success generated through external locus of control. This is the reason, because internal locus of control is more believed to be able to fulfill organizational goals than external locus of control which still depends on fate or luck in achieving its success.

\section{CONCLUSION}

From the discussion, revealing a negative and insignificant effect on locus of control on lecturer performance in achieving success. This indicates that the lecturer is not able to produce high performance. The lecturer's internal locus of control is still weak compared to the external locus of control. This situation occurs because lecturers are still not confident, their efforts and abilities are considered below average in producing success, because they prefer success depending on fate, luck and closeness through the authorities. In addition, locus of control also has a positive influence on lecturer performance through work motivation to produce high performance. Therefore, the success achieved by 
lecturers through Tri Dharma activities as a sign of confidence, independence, and ability to increase a strong workload is often supported by the motivation of other parties. Likewise with indirect influence through competence, they are also able to achieve success. This indicates that the lecturer has a strong belief in the workload at hand. Some jobs in the field of Tri Dharma do not create obstacles even though they are considered to be a strong burden in improving their performance, so that the problems faced are not obstacles in achieving success, and organizational demands on individual lecturers are believed to still be able to produce work performance in accordance with university goals.

Acknowledgements. As a thank you for participating in research for the development and improvement of the performance of university lecturers which has been funded by the university institution PGRI Adi Buana Surabaya, Indonesia.

\section{REFERENCES}

Ahluwalia, Mardeep Kaur and Kamal Preet. (2017). The Influence of Organizational Commitment On Work Motivation : A Comparative Study of State and Private University Teachers. The IUP Journal of Organizational Behavior. 16(2). 55-69. https://www.econbiz.de/Record/10011732440

Ahluwalia, Amardeep Kaur and Preet, Kamal. (2017). Work Motivation, Organizational Commitment and Locus of Control Vis-a-Vis Work Experience Amongst University Teachers. SAMVAD: SIBM Pune Research Journal. 14. 26-33. http://samvad.sibmpune.edu.in/index.php/samvad/article/download/118113/82888.

Alainati, Shaikhah; AlShawi, Sarmad N. and Al-Karaghouli, Wafi. (2011). The Effect of Education and Training on Competency. European, Mediterranean and Middle Eastern Conference on Information Systems 2011. Athens, Greece. https://bura.brunel.ac.uk/bitstream/2438/8489/2/.pdf.

Angelova, N. Virmozelova (2016). Locus of Control and Its Relationship with Some Social-Demographic Factors. In Psychological Thought. 9(2), 248-258. PsychOpen GOLD. https://doi.org/10.23668/psycharchives.1987.

Bartram, Dave. (2004). Assessment in Organization. Applied Psychology: An International Review. 53(2).237-259. DOI:10.1111/j.1464-0597.2004.00170.x. https://www.researchgate.net/publication/227865725.

Bernardin, John dan Joyce E.A. Russell. (2013). Human Resource Management. Singapore: Mc.Graw Hill.

Boyatzis, AR. (1982). Competent manager: A model of effective performance. New York: John Wiley \& Sons, Inc. https://www.researchgate.net/publication/253364682.

Dali, Nasrara, Masoud, Arifdin. (2014). Impact of Professionalism, Location of Control, and Job Satisfaction On Auditor Performance: Indonesian Evidence. An International Magazine for Enterprise Discovery and Management. 3(10). 63-73. http://karyailmiah.uho.ac.id/karya_ilmiah/Arifuddin/6.

Djou, LD Gadi and Lukiastuti, Fitri. (2020). The Impact of Competence and Locus of Control on the Performance of Government Internal Auditors Mediated by Jo 
Satisfaction at the Endez Regency Inspectorate. Advances in Health Science

Research. 27. 7-14. https://www.atlantis-press.com/article/125942122.pdf.

Fagbola Olaronke O. and Popoola Sunday O. (2015). Influence of Locus of Control, Work

Motivation and Information Use on Decision-Making of Managers in the Aviation

Industry in Nigeria. Library Philosophy and Practice (e-journal). University of

Nebraska - Lincoln.1-27.

https://digitalcommons.unl.edu/cgi/viewcontent.cgi?article=3658\&context=libphilpr ac.

Gibson James L., Ivancevich, John M. Donnelly, Jr. James H. and Konopaske Robert. (2013). Organizations Behavior, Structure, Processes. Fourteenth Edition. New York, The McGraw-Hill Companies, Inc.

Heywood, John S., Jirjahn, Uwe, Struewing, Cornelia. (2016). Locus of Control and Performance Appraisal. Econstor. IZA DP Paper No.10288.1-49. http://dx.doi.org/10.2139/ssrn.2861073.

Jung, J. (1978). Understanding Human Motivation: A Cognitive Approach. New York: Mc.Millan.

Kriswantini, Dwi and Sosositikno, Christina. (2020). The Effect Of Locus Of Control On The Performance Of Government Organiztions Eith The Internal Auditor Empowerment Variable As A Moderation Variable. Research Synergy Foundation. 1(1)58-63. http://proceeding.rsfpress.com/index.php/ic-smart/article/viewFile/27/23.

Kusuma, Aditya Halim Perdana, Rina, and Andi Hendra. (2018). The Main Role of Locus of Control and Professional Ethics on Lecturer's Performance (Indonesian Lecturer Empirical Study). International Review of Management and Marketing. 8(5), 9-17. https://www.econjournals.com/index.php/irmm/article/view/6884.

Lestariningsih, Marsudi. (2017). Self Efficacy and Achievement Motivation on Performance with Perceived Organizational Support Moderation (A Study on Private University Lecturer with "A" Accreditation Kopertis Region VII East Java). International Conference of Organizational Innovation, Advances in Intelligent Systems Research. 131.80-85. https://www.atlantis-press.com/proceedings/icoi$17 / 25880032$.

Luthans, Fred. (2015). Organizational Behavior: An Evidence Based Approach. Twelfth Edition, New York: McGraw-Hill/Irwin.

Mali, Vishal. (2013). Study on Locus of Control and its Impact on Employees' Performance. International Journal of Science and Research (IJSR). 2(12).149-151. https://www.ijsr.net/archive/v2i12/MDIwMTM1OTk=.pdf.

Mangkunegara, Anwar Prabu. (2017). Manajemen Sumber Daya Manusia Perusahaan, Cetakan Ketiga. Bandung: PT. Remaja Rosdakarya.

Maslow, A. H. (1987). Motivation and Personality (3rd ed.). Delhi, India: Pearson Education.

Mathis, Robert L. dan John H. Jackson. (2010). Manajemen Sumber Daya Manusia. Jakarta: Penerbit Salemba Empat.

Muindi, Florence. (2015). Quality of Work Life, Personality, Job Satisfaction, Competence, and Job Performance: A Critical Review of Literature. European $\begin{array}{lll}\text { Scientific Journal. } & \text { 223-240. }\end{array}$ https://eujournal.org/index.php/esj/article/view/6243. 
Mulyani, Sitti Rizki, Sari, Marta Widian, Sari, Vivi Nila, and Tawakalni, Winda. (2019). The Effect Locus of Control and Organizational Culture Toward Employee Performance with Organizational Commitments as Intervening Variable. JEMA: Jurnal Ilmiah Bidang Akuntansi dan Manajemen. 16(2).147-159. http://riset.unisma.ac.id/index.php/jema/article/view/2631.

Nerguz Bulut Serin, Oguz Serin and F. Sulen Sahin. (2010). Factors Affecting the Locus of Control of the University Students. Procedia Social and Behavioral Sciences. 2.449-452. https://pdf.sciencedirectassets.com/277811.

Mutai C. Loice (2014). Impact of Locus of Control on Employees' Perceptions of the Effectiveness of Performance Appraisals in the Kenya Revenue Authority (Southern Region). Thesis. School of Business, University of Nairobi. http://erepository.uonbi.ac.ke/handle/11295/77904.

Rachman, Mochammad Munir. (2012). Pengaruh Kemampuan Intelektual, Pembelajaran Individual, dan Internal Locus of Control terhadap Kompetensi dan Kinerja Dosen. Majalah Ekonomi. Tahun XXII. 1. 91-105.

Rachman, Mochammad Munir. (2017). The Influence of Work Culture on Job Satisfaction and Performance: A Study on the Employees of the Bank Jatim in Surabaya, East Java, Indonesia. European Journal of Business and Management. 9(26).30-39. https://iiste.org/Journals/index.php/EJBM/article/view/38791.

Rachman, Mochammad Munir. (2018). Metodologi Penelitian, Cetakan Kedua, Surabaya: Badan Penerbit Unipress Universitas PGRI Adi Buana Surabaya.

Rachman, Mochammad Munir. (2019). Aplikasi Komputer Statistik: Sebagai Pendukung Untuk Analisis Data Penelitian Dengan SPSS. Surabaya: Unipress, Universitas PGRI Adi Buana Surabaya.

Rachman, Mochammad Munir, Sugiyanto \& Siti Syamsiyah. (2020). The Influence of Transformational Leadership on the Performance of Employees with Motivation and Job Satisfaction as Intervening (A Study on the Office of the Department of Irrigation works in the District of Sidoarjo, Indonesia). European Journal of Business and Management. 12(14).12-23.

https://iiste.org/Journals/index.php/EJBM/article/view/52872

Ramsden, P. (2003). Learning to Teach in Higher Education (2nd ed.). London \& New York: Routledge Falmer. ISBN: 0415303451, 9780415303453. https://www.google.co.id/books/edition/Lqu1xm44Fi8C?

Robbins, Stephen P. and Judge, Timothy A. (2018). Organizational Behavior. London: Pearson Education Limited. https://books.google.co.id/books/about/Organizational_Behavior.html?id=_cwqtgE ACAAJ\&redir_esc $=y$.

Sundjoto. (2017). The Role of Internal Locus of Control on Intrinsic Motivation and Employee Performance of Ceramic Company in East Java. IOSR Journal of Business and Management. 19(7). Ver.VII.29-35. https://www.iosrjournals.org/iosr-jbm/papers/Version-7/E1907072935.

Sundari, Any. (2014). Community Based Politics: Empowering Women's Leaders in Yogyakarta. Jurnal Perempuan. 19(2).145-151. https://doi.org/10.34309/jp.v19i2.81. 
Susanne Rank and Teeradej Puapradit. (2017). Case Study About Germans And Thais: Impact Of Locus Of Control And Organization-Based Selr-Esteem On Affective Organizational Commitment \& Job Performance. Journal Of Intercultural Management. 9(2).53-79. https://doi.org/10.1515/joim-2017-0008.

Tiyanto PH., Prihatin. (2010). Kompetensi Dosen Hubungannya Dengan Praktek Organisasi Perguruan Tinggi Swasta di Kopertis Wilayah VI Jawa Tengah. Akses: Jurnal Ekonomi dan Bisnis. 5(9). 36-52. 